\title{
28 Research Square \\ Risk Perceptions, Attitude and Preventive Practices of Egyptians towards COVID-19
}

Nadira Mansour Hassan ( $\square$ nadera.hassan@med.tanta.edu.eg )

Tanta University faculty of Medicine https://orcid.org/0000-0002-3999-8301

\section{Safynaz El Saied Shalaby}

Tanta University faculty of Medicine

\section{Asmaa Ali EL-Feky}

Tanta University faculty of Medicine

\section{Eman Ali Younis}

Tanta University faculty of Medicine

\section{Asmaa Omar Attalla}

Tanta University faculty of Medicine

\section{Research Article}

Keywords: COVID-19, risk perception, attitude, preventive practices, students' satisfaction, distance learning, Egypt

Posted Date: October 13th, 2020

DOI: https://doi.org/10.21203/rs.3.rs-89882/v1

License: (c) (i) This work is licensed under a Creative Commons Attribution 4.0 International License. Read Full License

Version of Record: A version of this preprint was published at International Egyptian Journal of Nursing Sciences and Research on October 13th, 2020. See the published version at https://doi.org/10.21608/ejnsr.2021.90130.1072. 


\section{Abstract}

Background: COVID-19 is the latest global pandemic. To date, no antiviral treatment or vaccine has been explicitly recommended for it. Therefore, applying preventive measures to control its spread is the most critical intervention. Perceived risk and attitude determines population's reaction.

Objectives: study perceptions, attitude and practices towards COVID-19 among Egyptians

Methods: The study was cross-sectional using a snowball nonrandom sample from public population of Egyptian Community. They were asked to fulfill predesigned online questionnaire that was available from 16th to 24th March 2020.

Results: The study included 1663 participants from all governorates of Egypt. More than half were at age group $21-30$ years, $64.3 \%$ females and $85.1 \%$ students. Main source of information was social media (46.4\%). Most of Participants had positive attitude and moderate degree of fear. Only $25.4 \%$ of students satisfied with distance learning, $41.4 \%$ of participants believe that they are susceptible to infection and $61 \%$ believe in seriousness of the disease. About half of participants reported that they follow preventive precautions. Majority of participants (81.3\%) believe in effectiveness of these precautions. Participant's practices were relatively satisfactory except for wearing protective masks, movement of families outside home, reducing touch of nose and eyes, and getting enough sleeping hours. Binary logistic regression identified that significant predictors of good practice were female sex, belief in susceptibility, seriousness, and effectiveness of precautions.

On conclusion: Obligatory wearing of masks was an important governmental necessary step and to improve population reaction to control COVID-19, we need to promote realistic risk perceptions and effective attitudes.

\section{Introduction}

COVID-19 is the latest emerging infectious disease confronting the world. It was first discovered in December 2019, in Wuhan city, Hubei Province, China (1). COVID-19 is a respiratory disease, rapidly transmitted among people directly via respiratory droplets and secretion and indirectly through contaminated surfaces (2) (3). COVID-19 virus is highly contagious and with the aid of international transport, it has overcome geographical barriers achieving a remarkable proliferation and affection of large population causing most devastating effects globally (4) So, on the 11th of March 2020, WHO has declared COVID-19 as a global pandemic where most of the countries worldwide have registered COVID19 cases and deaths. $(5,6)$ At the beginning of June 2020, over 6.1 million cases and 165,000 deaths have been reported globally. (7) In different countries, including Egypt, global action plans have been put in place. Public health protocols started to control the spread of the virus, much of them related to proper hand washing, prevent shaking and kissing, social distancing, limiting public vehicle traffic, locking down public places that do not dispense essential services, and reducing traffic hours to certain daily hours. Since, to date no specific treatment or vaccine for that virus infection, management of this crisis depends 
mainly on adherence with preventive precautions $(8,9)$. That commitment is greatly influenced by knowledge, attitudes of the population (10). A recent study in Egypt showed good level of knowledge among its participants (11). Although knowledge is important for awareness of any problem, risk perception is a key factor that would contribute to attitudes and change public behaviour during outbreaks of global epidemics to prevent their spread (12). To contribute in management of these crises in Egypt it is mandatory to study risk perception, attitude and preventive measures taken by Egyptians to prevent COVID-19 infection and control its spread.

\section{Methods}

Study design:

Cross sectional study using a snowball nonrandom sampling technique. An online self-reported questionnaire was developed by using Google format with a consent attached to it. Google format was preferred for its convenience, efficiency and high popularity especially in the current situations of the epidemic that need social distance. The link of the questionnaire was sent through Facebook and WhatsApp to a group of 4th year medical students of Tanta University. Moreover, the link was published on some active websites. The participants were asked to roll out the questionnaire to their contacts and as many people as possible. Thus, the link was forward to many people apart from the initial contacts and so on. Respondents received a massage on the purpose of the study and its benefits. Information privacy and confidentiality were ensured. After acceptance they were asked to fulfill the questionnaire anonymously. The questionnaire was available on a web site from 16th to 24th March 2020.

The questionnaire was designed for this study after reviewing related published literatures on recent viral epidemics (SARS or MERS disease) (12-17). For validation of the questionnaire, it was reviewed by three experts and a pilot sample of 15 individuals used for pretesting the questionnaire (they were not included in the study). All notes were taken in consideration at the final form. Cronbach's alpha test was 0.75 indicating its reliability.

The questionnaire was initially structured in English then was translated into Arabic and back translated into English to validate language proficiency. Before distribution, the Arabic version was further reviewed by experts.

\section{The questionnaire included four main parts:}

First part related to sociodemographic data mainly: age, sex, governorate residents, occupation and main source of information about preventive precautions

Second part related to risk perceptions and include: believe in susceptibility to infection personally or family members, believe in seriousness of the disease, and believe in effectiveness of precaution procedures in prevention of the disease. 
Third part related to attitudes and expectations toward COVID-19 infection in Egypt: to what degree they were worry about (afraid of) COVID infection, expectations about spread of the disease in Egypt and expectations of its harmful effect

Fourth part related to preventive practices taken by the participant to avoid infection with COVID-19 and control its spread into the community and these were divided into three categories:

-Practices related to staying at home and avoiding crowded places (6 questions)

-Practices related to personal behaviour and hygienic measures (5 questions)

-Practices related to increasing immunity (3 questions)

At all practice questions participants select one of 3 possible answers (yes, to some extent and no). Yes was given 2 score, to some extent 1 score and no zero with a total score ranged 0-28.

An overall total score 0-16 $(<60 \%)$ was considered as poor practice and total score 17-28 was considered as good practice

\section{Statistical analysis:}

The collected data was encoded and statistically analyzed using statistical package for social studies (SPSS) version 22 created by IBM, Chicago, Illinois, USA. . Categorical data were presented as number and percentage. Chi-square test and odds ratio were used as a first order analysis followed by Binary logistic regression for independent variables that had significant association. The level of significance was $\mathrm{P}<5 \%$ with $95 \%$ confidence interval to identify significant predictors of good practice..

Ethical considerations: Participants were informed of the procedures and purpose of the study, and how they will benefit from the study. Data was collected anonymously with respect to privacy and confidentiality of participants and formal consent was obtained.

\section{Results}

The study included 1663 participants who was fulfill the study requirements (Egyptian, any age, sex, occupation and all educational levels, having a social media account and can manipulate with internet) and complete the questionnaire. They were distributed along all governorates of the country as shown at the figure

Table1. Showed that more than half (58.9\%) of participants at the age group 21-30 years, about two thirds (64.3\%were females, $85.1 \%$ were students and the vast majority were from Delta region. The main sources of information and advice were social media (46.4\%) followed by mass media and internet (44.6\%) (table1). 
Table (2) Pointed that $41.4 \%$ of participants thought that they are susceptible to infection and $14.4 \%$ were not; nearly the same percentages though that someone in their families could be infected. The main cause of fear of infection was that the disease may cause death (61\%). Meanwhile, $11.3 \%$ of participants were not afraid at all of infection. The majority of participants (81.3\%) believe in effectiveness of precautions against COVID-19 to prevent spread of the disease

As regards attitude towards COVID-19; table (3) showed that most of participants (74.4\%) expressed moderate degree of fear where $36.9 \%$ were just feel anxious and $37.5 \%$ were. somewhat afraid. Also, more than half of respondents expected that the disease either spread to small degree $(31.6 \%)$ or it will be controlled (26.6\%) and .41.8\% expected spread of the disease in Egypt to a large extent. Meanwhile, on enquiring about the expected harmful effect due to spread COVID-19 nearly one third (32.4\%) expressed psychological, $41.7 \%$ more than one harmful effect and $13.8 \%$ stated that no harm would affect them.

On enquiring participant students about agreement and satisfaction with distance learning only about $25.4 \%$ were either agree or completely agree, $60.4 \%$ were not agree and $14.3 \%$ don't know.

Regarding adherence to preventive measures of COVID-19, about half (49.4\%) of participants stated that they follow precautions to prevent spread of the virus and $45.1 \%$ found it difficult but trying to follow only $1.6 \%$ reported that they don't believe in its usefulness (table 4 )

Regarding to practices related to staying at home and avoiding crowded places. More than two thirds $(69.7 \%)$ of participants were trying to stay at home as long as possible, $46.8 \%$ of their family members tries not to leave home to some extent .Great majority (83.3\%) not going to school or work, $74.7 \%$ avoid eating in restaurant, $64.6 \%$ reducing public transport travel and $71.8 \%$ were avoiding large gathering places. Meanwhile, Practices related to personal behavior and hygienic measures table (5) indicated that $84.8 \%$ of participants wash hands with soap and water well, only $46.8 \%$ were using antiseptics to sterilize surfaces and handles, $51.4 \%$ trying to reduce touching nose and eyes with hands to some extent, $54.4 \%$ avoid shaking hands and kissing but only $17.1 \%$ were wearing protective masks currently in crowded places. On the other hand, regarding participants' practices to increase their immunity, $65.4 \%$ drink enough water and liquids, $60.8 \%$ were trying to eat balanced diet, and more than half of them (59.7\%) get enough sleeping hours.

The vast majority (81.9\%) of participants had good level of adherence to preventive precautions and this was significantly associated with female sex ( $O R=0.613, P<001)$, believe in susceptibility to infection $(O R=0.433, P<0.001)$, believe in seriousness of the disease $(O R=0.489, P<0.001)$, believe in effectiveness of preventive measures $(\mathrm{OR}=3.359 . \mathrm{P}<0.001)$ and expectation of presence of harmful effect $(\mathrm{OR}=0.613, \mathrm{P}=0.003)$ (table 6)

By binary logistic regression Table (7) pointed that female sex ( $A O R=0.702, P=0.009$ ), believe in susceptibility $(A O R=0.608, P=0.004)$, believe in seriousness $(A O R=0.638, P=0.002)$ and believe in effectiveness of preventive measure ( $A O R=3.04, P=0.009$ ) were the significant predictors of good score practice level 


\section{Discussion}

Since $11^{\text {th }}$ March 2020 the world confronted COVID-19 pandemic. All countries have imposed strict control measures to prevent massive spread and reduce mortality. As up to date there is no vaccination or ensured treatment, adherence to preventive precautions is mandatory. Various degrees of adherence were reported among different populations, some show strict adherence (18) and others were not (19). Egypt is the most populous country in the Middle East and about $95 \%$ of the population lives along banks of the Nile river and its Delta, which lies north of Cairo (capital of Egypt); and along the Suez Canal. These regions are considered as one of the most densely populated regions in the world. It contains an average of over 3,820 persons per square mile $\left(1,540 \mathrm{per} \mathrm{km}^{2}(20)\right.$. So, adherence to preventive precautions is essential to prevent the crisis in Egypt which needs a mitigation effort to reduce community spread and the overwhelming of the country's health system. To get the required level of adherence, it is important to evaluate perception and attitude of the population so we can interpret their behavior. In the current study the majority of respondents were students, females, under 30 years and from delta region of Egypt. This could be explained by the online nature of the survey and its starting point by students. Besides, many studies reported female predominance $(21,22,23)$. Also, the same age group was documented in Peruvian and Bangladesh studies $(19,24)$ ). In nearly all previous studies (including Egypt) about COVID19 , the novel methods of communications, social media (commonly Facebook and WhatsApp) were the main source of information, and the same was for the participants of this study. Social media and internet attract youth and young adult (25).So, policy makers should pay great effort to reach this wide sector of the population which could affect other categories.

Understanding the people's perception of risk is important to ensure efficient health protection practices during virus outbreaks (21). In the present study, only $14.4 \%$ of respondent believe that they are not susceptible to infection with COVID-19 and the vast majority believe in their susceptibility either absolute $(41.4 \%)$ or relative $(44.4 \%)$ and nearly the same percentages for members of their families. Moreover, about three quarters believe in seriousness of the disease. Putting in mind that, people make judgments based on their own perception of risk and not on the real risk (12) together with frequent exposure to worldwide news about infection and deaths from social media and TV channels, could explain our finding. This was in consistence with a previous study carried out in Egypt (11) and Venezuela (19). On the other hand, the vast majority of participant at the current study believe in effectiveness of preventive precautions, and this was reflected on their attitude where $74.4 \%$ of them were just feel anxious or just worry. A moderate degree of fear is good and could push individuals towards commitment with preventive precautions. Previous studies reported that both reluctance (19) and sever fear and anxiety $(21,27,28)$ are not good for mental health and compliance with preventive measures. Moreover, the optimistic attitude of our participants reflected on their practice where only $5.5 \%$ reported that they don't follow preventive precautions, the rest either follow (49.4.9\%) or try to follow precautions (45.1\%) to avoid infection and prevent its spread in the community:

In the present study, more than half of participants were optimistic and expect that, COVID-19 spread will either to a small degree or will be controlled. This means that Egypt will win the battle. This was the same 
attitude of respondents in studies carried out in, china, Malaysia and Saudi Arabia $(18,22,23)$ However, participants expected that spread of the infection will have a bad impact on their health due to its psychological, economic and physical harmful effect.

Although participants' students staying at home due to closure of their learning institutions only one quarter of them were satisfied of the distance e-learning more study is needed to evaluate this point.

Regarding preventive practices related to staying at home and avoiding crowded places; the most of our participants not going school or work, avoid eating in restaurants, stay at home, avoid crowded places, and reducing public transport travel. This may be due to the nature of the sample where most of respondents were students and females and the early governmental control measures that lead to closure of the governmental and special educational institutions. In our Egyptian community students spends long hours at university or educational institutions, they mostly eat outside homes in restaurants. When students stay at home there is a good chance to eat balanced diet and drink adequate amount of water and fluids to increase their immunity. In previous studies washing hands, personal hygiene and clean environment were reported by high proportions of respondents $(19,22,28)$. In the meantime limited use of face masks was manifest among the Peruvian population like Egyptians in the present study. Defect in awareness of when, how, where and why to wear face masks may be the cause. This was in agreement with the findings of a study carried out in Bangladesh where most of its participants indicated negligence about severity of the disease and reluctance to use facemasks (24). The condition was the reverse among Chinese people who had experience in SARS epidemic (18).

Our study showed that about half of participants didn't have enough sleeping hours which is important for increasing immunity this may be due to spending long hours with internet and social media which is common among students nowadays.

On assessment of the overall total score of our participant the vast majority (81.9\%) were had good practice which was statistically significant with female sex, believe in susceptibility ,believe in seriousness, believe in effectiveness of preventive precautions and expectation of harmful effect of spread of the disease. On the other hand, with binary logistic regression, only harmful effect become insignificant while believe in effectiveness of precautions show marked weight of association. This could explain the high level of compliance among our participants globally; Female showed more compliance, a finding that may be of great importance as targeting of women in health education dissemination may ultimately yield improved implementation of preventive precautions among all elements of the community. Also, it was documented that lack people's confidence to health national authorities and effectiveness of measures to deal with COVID-19 outbreak lead to limited response of the population (19).

\section{Strengths and Limitation:}

The strength of this study lies on its large sample recruited from all governorates of Egypt during a critical period at the initial stage of the COVID-19 epidemic 
Limitations of the study focus mainly on type of the sample and method of data collection that were used with their consequences. Due to the limited time and urgency of the survey, the study use snowball sampling starting from students who had access to internet and social media. So, this study mostly represents the young educated population and could not be generalized to the whole Egyptians.

The study used self-reported questionnaire so it is possible that participants may have answered practice questions positively based on what they perceive to be expected of them. (29)

\section{Conclusion}

- Obligatory wearing of masks was an important governmental necessary step and to improve population reaction to control COVID-19, we need to promote realistic risk perceptions and effective attitudes. Students' satisfaction with distance learning needs more investigation.

-A more systematic, inclusive sampling method is recommended to improve representativeness and generalizability of the findings and explain the limited adherence to preventive procedures among the general population in Egypt.

\section{Declarations}

\section{Ethics and consent to participate:}

"Ethical approval: "All procedures performed in this study were in accordance with the1964 Helsinki declaration and its later amendments or comparable ethical standards. Also, it was in accordance with the ethical standards of the Ethical Committee of Scientific Research of Faculty of Medicine, Tanta University, Federal Wide Assurance (FWA 00022834),

IRB 0010038) and approved (reference number 34086)"

\section{Informed consent:}

"Informed consent was obtained from all individual participants included in the study. The participants were told about the aim of the study, and they were informed that the data would be used for scientific purposes only. They were also given the right to refuse or participate in the study. Submission of the questionnaire after completing it considered as more confirmation for acceptance of participation.

\section{Consent for publication:}

- Not applicable

\section{Availability of data and material:}

- Available from the corresponding author on reasonable request 
Competing interest:

The authors declare no competing interest

\section{Funding:}

- No available fundus

\section{Authors' contribution}

$\mathrm{NMH}$ : Conceptualization, writing methodology, work in the analysis and interpretation of data, writing original draft, editing.

SSS: take part in designing the questionnaire, reviewing the final manuscript for important intellectual content, editing

AAF: data collection, take part in data curation, writing original draft

EAY: take part in: data collection, take part in data curation, writing original draft

AOA: data collection, take part in data curation and writing original draft

All authors read and approved the final manuscript to be published

\section{Acknowledgement:}

Thanks to all participants and our students at $4^{\text {th }}$ year medical at Tanta University who were the initial starting points of the study and their leader Mahmoud harass for his active participation and formatting the questionnaire at Google format.

\section{References}

1). Wu F, Zhao S, Yu B, Chen Y-M, Wang W, Song Z-G, et al. A new coronavirus associated with human respiratory disease in China. Nature.(2020) 579:265 -9. doi: 10.1038/s41586-020-2008-3

2) .Shereen MA, Khan S, Kazmi A, Bashir N, Siddique R. COVID-19 infection: origin, transmission, and characteristics of human coronaviruses. J Adv. Res. (2020) 24:91-8. doi: 10.1016/j.jare.2020.03.005

3) Parry J. China coronavirus: cases surge as official admits human to human transmission. BMJ. (2020) 368:m236. doi: 10.1136/bmj.m 236

4) Guo, Y. R., Cao, Q. D., Hong, Z. S., et al. (2020).The origin, transmission and clinical therapies on coronavirus disease 2019 (COVID-19) outbreak - an update on the status. Military Medical Research, 7(1), 
5) WHO 2020d Corona Virus Disease 2019 (COVID-19) -Situation Report-70

6) WHO Director-General's opening remarks at the media briefing on COVID-19 11 March 2020. Retrieved April 4, 2020, from https://www.who.int/dg/speeches/detail/who-director-general-s-openi ng-remarks-atthe-media-briefing-on-covid-19-11-march-2020

7) World Health Organisation. Corona virus disease 2019 (COVID-19). Situation Report - 90. Geneva: WHO. (2020). Available online at: www.who.int/emergencies/diseases/novel-coronavirus-2019/situationreports (accessed June5, 2020).

8) Koo, J.R.; Cook, A.R.; Park, M.; Sun, Y.; Sun, H.; Lim, J.T.; Tam, C.; Dickens, B.L. Interventions to mitigate early spread of SARS-CoV-2 in Singapore: A modeling study. Lancet Infect. Dis.2020. [CrossRef]

9) Prem, K.; Liu, Y.; Russell, T.W.; Kucharski, A.J.; Eggo, R.M.; Davies, N.; Jit, M.; Klepac, P.; Flasche, S.; Clifford, S.; et al. The effect of control strategies to reduce social mixing on outcomes of the COVID-19 epidemic in Wuhan, China: A modelling study. Lancet Public Health 2020, 5, 261-270. [CrossRef)

10) Tachfouti, N.; Slama, K.; Berraho, M.; Nejjari, C. The impact of knowledge and attitudes on adherence to tuberculosis treatment: A case-control study in a Moroccan region. Pan Afr. Med. J. 2012, 12, 52. [PubMed]

11) Ahmed Samir Abdelhafz, · Zeinab Mohammed, Maha Emad Ibrahim, Hany H. Ziady, · Mohamed Alorabi, Mohamed Ayyad, Eman A. Sultan.Knowledge, Perceptions, and Attitude of Egyptians towards the Novel Coronavirus Disease (COVID-19). Journal of Community Health. Available onlinehttps://doi.org/10.1007/s10900-020-00827-7

12) Smith RD. Responding to global infectious disease outbreaks: lessons from SARS on the role of risk perception, communication and management. Soc Sci Med. 2006;63(12):3113- 3123. doi:10.1016/j.socscimed.2006.08.004

13) Lau JTFF, Kim JH, Tsui HY, Griffiths S. Anticipated and current preventive behaviors in response to an anticipated human-to-human H5N1 epidemic in the Hong Kong Chinese general population. BMC Infectious Diseases. 2007;7(1):18.

14) Lau JTFF, Kim JH, Tsui H, Griffiths S. Perceptions related to human avian influenza and their associations with anticipated psychological and behavioral responses at the onset of outbreak in the Hong Kong Chinese general population. American Journal of Infection Control. 2007;35(1):38-49.

15) Lau JTFF, Yang X, Pang E, Tsui HY, Wong E, Yun KW, et al. SARS-related Perceptions in Hong Kong. Emerging Infectious Diseases. 2005;11(3):8. 
16). Abbag HF, El-Mekki AA, Al Bshabshe AAAA, Mahfouz AA, Al-Dosry AA, Mirdad RT, et al. Knowledge and attitude towards the Middle East respiratory syndrome coronavirus among healthcare personnel in the southern region of Saudi Arabia. Journal of Infection and Public Health. 2018; 11(5):720-2.

17) Brug J, Aro A R, Oenema A, de Zwart O, Richardus JH, Bishop JD. SARS Risk Perception, Knowledge, Precautions, and Information Sources, the Netherlands. Emerging Infectious Diseases • www.cdc.gov/eid - Vol. 10, No. 8, August 2004

18) Zhong B-L, Luo W, Li H-M, Zhang Q-Q, Liu X-G, Li W-T, Li Y. Knowledge, attitudes, and practices towards COVID-19 among Chinese residents during the rapid rise period of the COVID-19 outbreak: a quick online cross-sectional survey. International Journal of Biological Sciences. 2020;16(10):1745-52.

19) Zegarra-Valdivia, J. A. ; Chino-Vilca, B. N. , Ames-Guerrero, R. Knowledge, perception and attitudes in Regard to COVID-19 Pandemic in Peruvian Population. Preprint . April 2020.

DOI: 10.31234/osf.io/kr9ya. https://www.researchgate.net/publication/340694053

20) The Central Agency for Public Mobilization and Statistics Website (2020). Retrieved. April 4, 2020, from https://www.capmas.gov. eg/Pages/populationClock.aspx\#

21) Roya D , Tripathya S , Kara S-K, , Sharmaa N , Vermaa S-K, Kaushalb V. Study of knowledge, attitude, anxiety \& perceived mental healthcare need in Indian population during COVID-19 pandemic. Asian Journal of psychiatry 51(2020) 102083

22) Azlan AA, Hamzah MR, Sern TJ, Ayub SH, Mohamad E (2020) Public knowledge, attitudes and practices towards COVID-19: A cross-sectional study in Malaysia. PLoS ONE 15(5): e0233668. https://doi.org/10.1371/journal.pone.0233668

23) Al-Hanawi MK, Angawi K, Alshareef N, Qattan AMN, Helmy HZ, Abudawood Y, Alqurashi M, Kattan WM, Kadasah NA, Chirwa GC and Alsharqi O (2020) Knowledge, Attitude and Practice Toward COVID-19 Among the Public in the Kingdom of Saudi Arabia: A Cross-Sectional Study. Front. Public Health 8:217. doi: $10.3389 /$ fpubh.2020.00217

24) Ferdousa MZ. Islama,S,. Sikdera $T$, .. Mosaddekc,d AS,. Zegarra-Valdiviae JA, Gozalf D. Knowledge, attitude, and practice regarding COVID-19 outbreak in Bangladesh: An online-based cross-sectional study. medRxiv preprint doi: https://doi.org/10.1101/2020.05.26.20105700.this version posted June 3, 2020.

25) Sannusi SN, Ibrahim F, Shaari AH, Subhi N.The use of social media among adolescents in Klang Valley. J Komun Malays J Commun. 2019; 35(4):101-118.

26) Corrin T, Waddell L, Greig J, Young I, Hierlihy C, Mascarenhas M. Risk perceptions, attitudes, and knowledge of chikungunya among the public and health professionals: a systematic review. Trop Med Health. $2017 ; ; 45(1): 1-15$. 
27) Shigemura, J , Ursano R J,. Morganstein JC, Kurosawa M, Benedek, DM. Public responses to the novel 2019 coronavirus (2019-nCoV) in Japan: Mental health consequences and target populations. Psychiatry and Clinical Neurosciences 74: 277-283, 2020. doi:10.1111/pcn.12988

28) Zipprich HM , Teschner U, Witte OW, Schönenberg A, Prell T. Knowledge, Attitudes, Practices, and Burden During the COVID-19 Pandemic in People with Parkinson's Disease in Germany. J. Clin. Med. 2020, 9, 1643; doi: 10.3390/jcm9061643

29) Van de Mortel TF. Faking it. social desirability response bias in self-report research. Aust J Adv Nurs. 2008; 25(4):40-48.

\section{Tables}

Table (1): Socio-demographic characteristics and main source of information of studied participants 


\begin{tabular}{|c|c|c|}
\hline \multirow[t]{2}{*}{ Variables } & \multicolumn{2}{|l|}{ Total } \\
\hline & $\mathrm{N}=1663$ & $\%$ \\
\hline \multicolumn{3}{|l|}{ Age: } \\
\hline$\leq-20$ years & 593 & 35.7 \\
\hline $21-30$ years & 979 & 58.9 \\
\hline $31-40$ years & 47 & 2.8 \\
\hline $41-50$ years & 27 & 1.6 \\
\hline More than 50 & 17 & 1.0 \\
\hline \multicolumn{3}{|l|}{ sex: } \\
\hline Male & 593 & 35.7 \\
\hline Female & 1070 & 64.3 \\
\hline \multicolumn{3}{|l|}{ Residence: } \\
\hline Delta & 1566 & 94.2 \\
\hline Greater Cairo & 70 & 4.2 \\
\hline Upper Egypt & 27 & 1.6 \\
\hline \multicolumn{3}{|l|}{ Occupation: } \\
\hline Student & 1415 & 85.1 \\
\hline Employee & 168 & 10.1 \\
\hline Don't work & 80 & 4.8 \\
\hline \multicolumn{3}{|c|}{ Source of information and advice: } \\
\hline \multicolumn{3}{|l|}{-Social media } \\
\hline \multicolumn{3}{|c|}{-Internet and mass media } \\
\hline - TV only & 771 & 46.4 \\
\hline \multirow[t]{3}{*}{ - others } & 742 & 44.4 \\
\hline & 80 & 4.8 \\
\hline & 70 & 4.4 \\
\hline
\end{tabular}


Table (2): Perception of susceptibility, seriousness of the disease and effectiveness of preventive precautions in its control

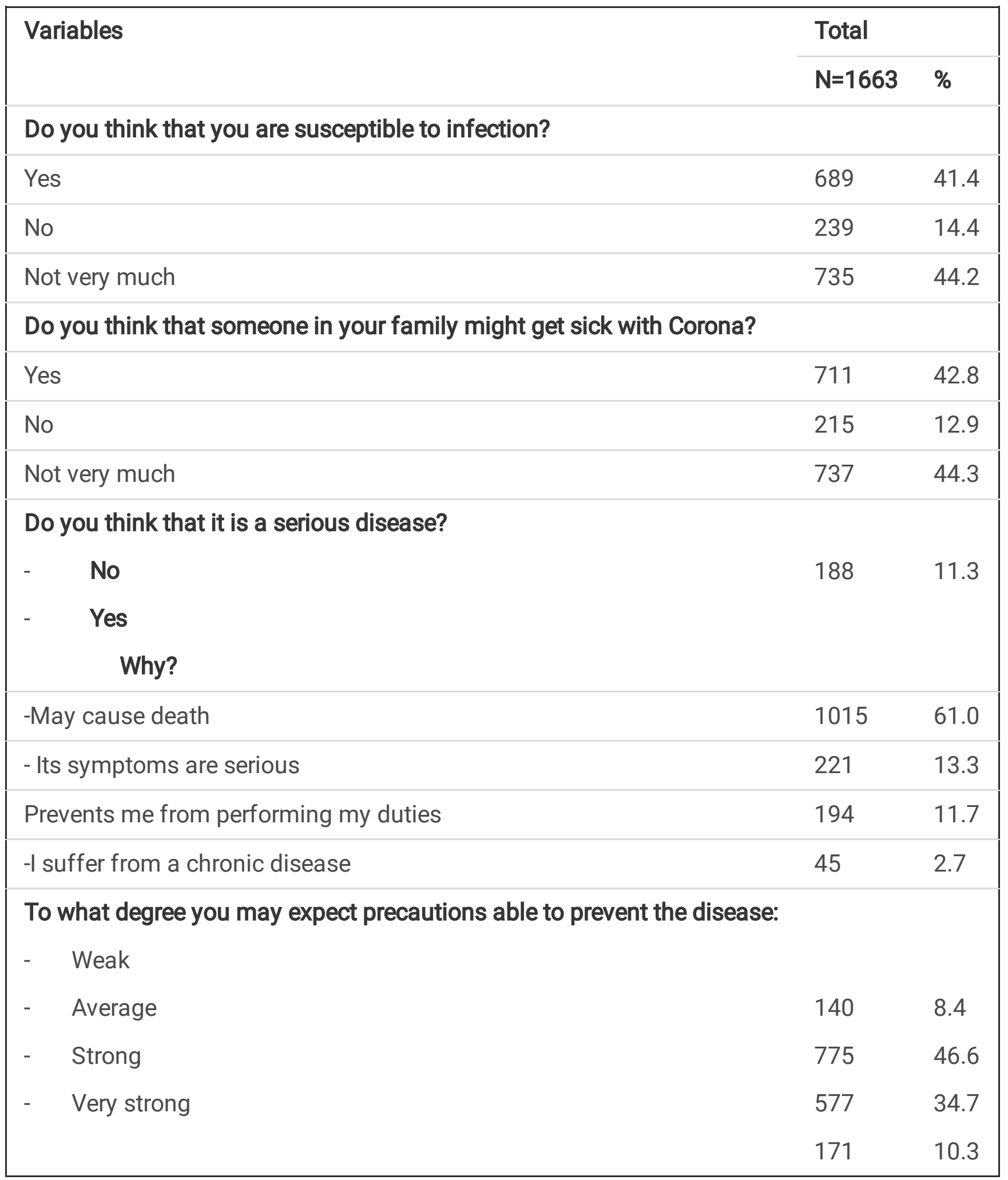

Table (3): Attitudes and expectations toward COVID-19 among studied participants 


\begin{tabular}{|lll|}
\hline Attitude and expectations & $\mathrm{N}=1663$ & $\%$ \\
\hline How often do you get afraid of corona infection? & & \\
\hline - $\quad$ I don't feel afraid at all & 148 & 8.9 \\
\hline - I just feel anxious & 614 & 36.9 \\
\hline - $\quad$ Somewhat afraid & 624 & 37.5 \\
\hline - Very afraid & 277 & 16.7 \\
\hline Do you expect Corona to spread in Egypt to a large degree (attitude) & & \\
\hline - Yes, it will spread to a large extent & 695 & 41.8 \\
\hline - It will spread but to a small degree & 525 & 31.6 \\
\hline It will be controlled & 443 & 26.6 \\
\hline What kind of harm could affect you by spread of Corona virus & & \\
\hline -Physical only & 34 & 2.0 \\
\hline -Psychological only & 630 & 37.9 \\
\hline -Economic only & 94 & 5.7 \\
\hline -More than one harm & 669 & 40.2 \\
\hline -There is no harm & 236 & 14.2 \\
\hline For students (1415) & 263 & 18.6 \\
\hline Do agree ( satisfied ) with distance learning & 96 & 6.8 \\
\hline$\quad$ - Not agree & 202 & 14.3 \\
\hline$\quad$ - Complee & & 60.4 \\
\hline
\end{tabular}

Table (4): Participant's adherence to preventive measures of COVID-19 


\begin{tabular}{|c|c|c|c|c|c|c|}
\hline \multirow[t]{4}{*}{ Variables } & \multicolumn{6}{|c|}{ Total $(n=1663)$} \\
\hline & \multicolumn{2}{|l|}{ Yes } & \multicolumn{2}{|l|}{ No } & \multirow{2}{*}{\multicolumn{2}{|c|}{$\begin{array}{l}\text { I find it difficult } \\
\text { But I try to } \\
\text { follow }\end{array}$}} \\
\hline & & & & & & \\
\hline & $\mathbf{n}$ & $\%$ & $\mathbf{n}$ & $\%$ & $\mathrm{n}$ & $\%$ \\
\hline \multicolumn{7}{|c|}{$\begin{array}{l}\text { Do you follow precautions that prevent spread of } \\
\text { Corona }\end{array}$} \\
\hline Yes & 821 & 49.4 & 92 & 5.5 & 750 & 45.1 \\
\hline No & 92 & 5.5 & & & & \\
\hline Difficult to do & & & 60 & 3.9 & & \\
\hline I do not believe it is useful & & & 32 & 1.6 & & \\
\hline
\end{tabular}

Table (5): Self-reported participants' practices to prevent infection by COVID- 19 
Total $(n=1663)$

$\begin{array}{lll}\text { Yes No } & \begin{array}{l}\text { To some } \\ \text { extent }\end{array}\end{array}$

No. $\%$ No. $\%$ No.

Practices related to staying at home and avoiding crowded places: 1-Trying to stay at home as long as possible

\begin{tabular}{|c|c|c|c|c|c|c|}
\hline & 1159 & 69.7 & 180 & 10.8 & 324 & 19.5 \\
\hline $\begin{array}{l}\text { 2- Family members families tries not to leave home } \\
\text { as possible }\end{array}$ & 706 & 42.5 & 178 & 10.7 & 779 & 46.8 \\
\hline 3-Reducing public transport travel & 1075 & 64.6 & 302 & 18.1 & 287 & 17.3 \\
\hline 4-Not going to school or work & 1385 & 83.3 & 140 & 8.4 & 138 & 8.3 \\
\hline 5- Avoid large gathering places & 1194 & 71.8 & 70 & 4.2 & 399 & 24.0 \\
\hline 6-Avoid eating in restaurants & 1242 & 74.7 & 116 & 7.0 & 305 & 18.3 \\
\hline \multicolumn{7}{|l|}{$\begin{array}{l}\text { Practices related to personal behavior and hygienic } \\
\text { measures }\end{array}$} \\
\hline 1-Wash hands with soap and water well & 1410 & 84.8 & 20 & 1.2 & 233 & 14.0 \\
\hline 2-Use antiseptics to sterilize surfaces and handles & 778 & 46.8 & 362 & 21.8 & 523 & 31.4 \\
\hline $\begin{array}{l}\text { 3- Trying to reduce touching nose and eyes with } \\
\text { hands }\end{array}$ & 612 & 36.8 & 197 & 11.8 & 854 & 51.4 \\
\hline 4-Avoiding shaking hands and kissing & 905 & 54.4 & 154 & 9.3 & 604 & 36.3 \\
\hline $\begin{array}{l}\text { 5-Wearing protective masks currently in crowded } \\
\text { places }\end{array}$ & 285 & 17.1 & 1090 & 65.6 & 288 & 17.3 \\
\hline \multicolumn{7}{|l|}{ Practices related to increasing immunity } \\
\hline 1-Be sure to drink enough water and liquids & 1087 & 65.3 & 121 & 7.3 & 455 & 27.4 \\
\hline 2- Trying to eat balanced diet & 1011 & 60.8 & 462 & 27.8 & 190 & 11.4 \\
\hline 3-Get enough sleep & 993 & 59.7 & 137 & 8.2 & 533 & 32.1 \\
\hline
\end{tabular}


Table (6): Factors affecting practice level of following preventive precautions against COVID-19 infection among participants 


\section{Variable}

Practice level

$\begin{array}{ll}\text { Poor } & \text { Good } \\ \text { practice } & \text { practice }\end{array}$

no $=303$

(18.1\%)

Sex

- Female

- Male

Residence

- Delta region

- others

\section{Occupation}

- student

- others

$$
\begin{array}{llll}
165(54.8 \%) & 905(66.4 \%) & X^{2}=14.531 & 0.613(0.476- \\
136(45.2 \%) & 457(33.6 \%) & P=0.0001 * &
\end{array}
$$

\begin{tabular}{|c|c|c|c|}
\hline - $\quad$ Susceptible & $228(75.7 \%)$ & $\begin{array}{l}1196 \\
(87.8 \%)\end{array}$ & $X^{2}=29.157$ \\
\hline Not susceptible & $73(24.3 \%)$ & $166(12.2 \%)$ & $P=0.0001^{*}$ \\
\hline
\end{tabular}

\section{Belief in susceptibility to infection}

\section{Belief seriousness of infection \\ Belief seriousness of infection}

$$
\begin{array}{rlll}
248(82.4 \%) & 1167(85.7 \%) & X^{2}=2.104 & 0.783(0.56- \\
53(17.6 \%) & 195(14.3 \%) & P=0.147 &
\end{array}
$$

$0.842(0.506-$

1.400)
- Serious

- $\quad$ Not serious
187(62.1\%) $1049(77 \%) \quad X^{2}=28.651$

$114(37.9 \%) \quad 313(23 \%) \quad \mathrm{P}=0.0001$ *
$0.489(0.376-$

$0.638)$

\section{Belief in effectiveness of}

precautions

- $\quad$ Not effective

- $\quad$ Effective in various degrees

$\begin{array}{llll}55(18.3 \%) & 85(6.2 \%) & \mathrm{X}^{2}=46.287 & 3.359(2.33- \\ 246(81.7 \%) & 1277 & \mathrm{P}=0.0001 * & \\ & (93.8 \%) & \end{array}$

Harmful effect: 


\begin{tabular}{|lllll|}
$-\quad$ Present & $242(80.4 \%)$ & $1185(87 \%)$ & $X^{2}=8.834$ & $0.613(0.442-$ \\
$-\quad$ Absent & $95(19.6 \%)$ & $177(13 \%)$ & $P=0.003^{\star}$ & \\
\hline
\end{tabular}

\section{*significant}

Table (7): Binary logistic regression for factors associated with good score practice level

\begin{tabular}{|llll|}
\hline Factors associated with good score practice level & Wald & $p$ & Adjusted odds ratio (AOR) \\
\hline Female sex & 6.824 & $0.009^{*}$ & 0.702 \\
\hline Belief in susceptibility to infection & 8.347 & $0.004^{*}$ & 0.608 \\
\hline Belief in seriousness of COVID-19 infection & 9.317 & $0.002^{*}$ & 0.638 \\
\hline Presence of harmful effect & 3.323 & 0.068 & 0.728 \\
\hline Belief in effectiveness of precautions & 33.489 & $0.0001^{*}$ & 3.040 \\
\hline
\end{tabular}

*significant

Figures 


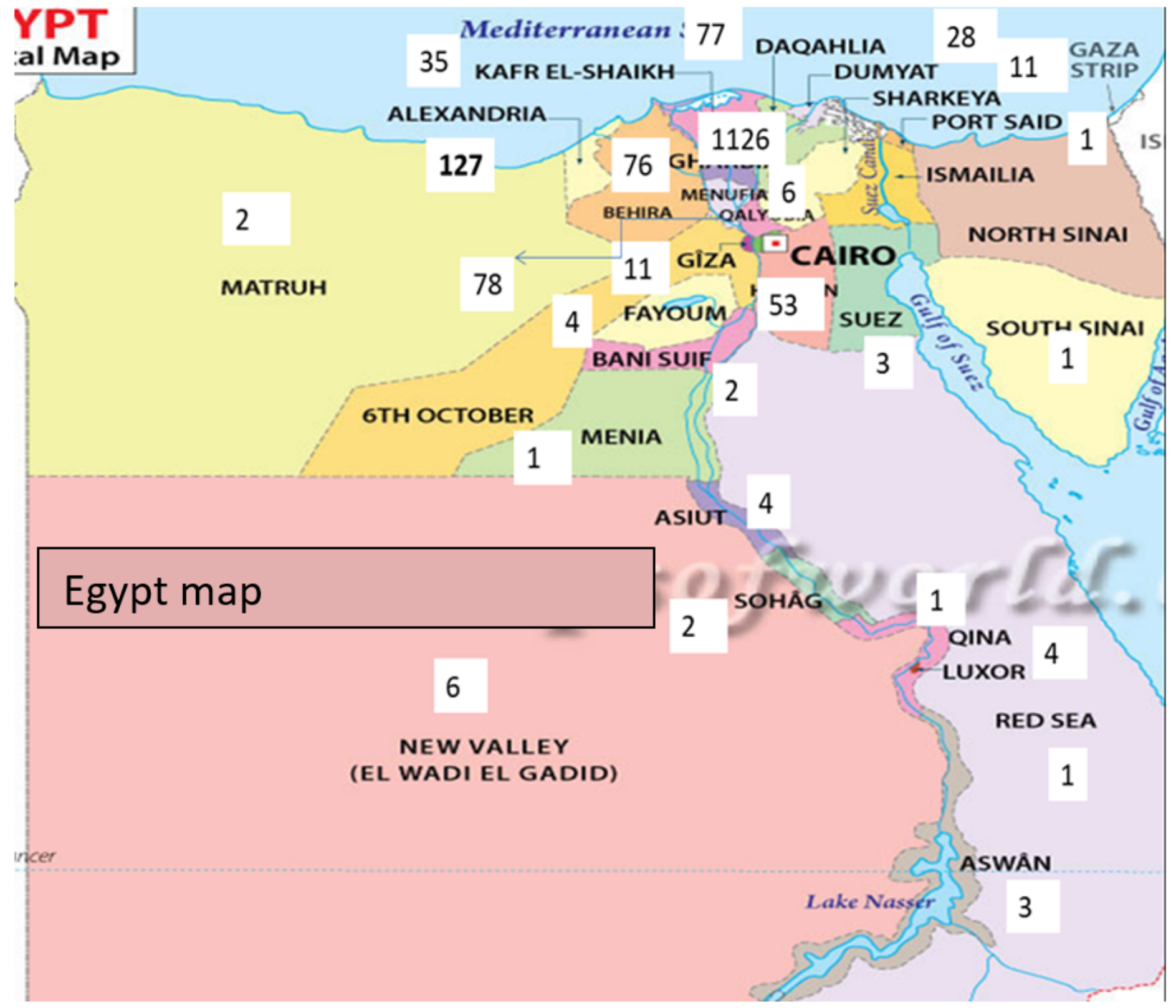

Figure 1

Geographical distribution of participants' study 